\title{
UZBROJENIE I WYPOSAŻENIE SIE IRLANDZKIEJ ARMII REPUBLIKAŃSKIEJ PODCZAS WOJNY O NIEPODLEGŁOŚĆ IRLANDII W LATACH 1919-1921
}

Streszczenie. W artykule analizowana jest kwestia logistyki oraz zaplecza wojny o niepodległość Irlandii w latach 1919-1921. Badane kwestie to: stan finansów obu stron konfliktu oraz metody pozyskiwania funduszy na prowadzenie wojny, kwestia broni palnej, jej pozyskiwania, produkcji, a także zastosowanie środków wybuchowych. Zbadane zostały środki transportu używane przez obie strony oraz przeanalizowano ich wpływ na zmiany w taktyce walki. Opisano także problemy związane z pomocą medyczną, umundurowaniem i aprowizacją. Praca oparta jest na relacjach świadków wydarzeń zebranych przez Biuro Historii Militarnej Irlandii.

Słowa kluczowe: logistyka, wyposażenie, uzbrojenie, Irlandzka Armia Republikańska, transport, środki wybuchowe, broń palna, finanse.

7 ematem niniejszego artykułu jest kwestia logistyki i szeroko pojętego zaplecza wojny o niepodległość Irlandii w latach 1919-1921. W hi-

1 storiografii konflikt ten funkcjonuje pod wieloma nazwami. Oprócz wcześniej użytego zwrotu stosuje się terminy takie jak: „wojna angielsko-irlandzka”, „,brunatna wojna” (ang. Tan War). Gaelicka ${ }^{1}$ nazwa to Cogadh na Saoirse, termin ten oznacza dokładnie „wojnę o wolność”.

Jako ramy czasowe wskazuje się tradycyjnie lata 1919-1921. Podstawowym źródłem podczas badań nad historią wojny o niepodległość Irlandii są zeznania uczestników konfliktu, będące w posiadaniu Irlandzkiego Biura Historii Militarnej, placówki założonej w 1947 r. przez ministra obrony Irlandii

${ }^{1}$ Irlandzki język gaelicki - język z grupy goidelskiej języków celtyckich. Obecnie język urzędowy Irlandii obok języka angielskiego. 
- Oscara Traynora². Kolekcja zawiera 1773 zeznania osób biorących udział w wydarzeniach od 1916 do 1922 r. Akta dotyczą zarówno działalności militarnej (udział w powstaniu, członkostwo w organizacji Irlandzkich Ochotników, Irlandzkiej Armii Republikańskiej etc.), jak i działalności społecznej lub politycznej (praca w administracji rodzącego się państwa irlandzkiego, działalność polityczna partii Sinn Féin ${ }^{3}$, praca wywiadu). W marcu 1951 r. zeznania w języku angielskim, wraz z zestawem dokumentów, nagraniami i fotografiami, zostały zabezpieczone i zapieczętowane. Kolekcję udostępniono dopiero w marcu $2003 \mathrm{r}$. Zdigitalizowane dokumenty umieszczono w Internecie w $2012 \mathrm{r}^{4} \mathrm{Na}$ gruncie irlandzkim stworzono na ich podstawie wiele prac naukowych, jednak w Polsce do tej pory nie funkcjonowały one w obiegu naukowym, oprócz mojego artykułu pt. Ewolucja taktyki wojennej Irlandczyków i Brytyjczyków podczas wojny o niepodległość Irlandii w latach 1919-19215. Niniejsza praca będzie się jednak skupiać na kwestiach związanych z zapleczem wojny o niepodległość Irlandii. Są to zagadnienia mniej porywające niż opis działań wojennych; działania, związane z zaopatrzeniem, wyżywieniem i uzbrojeniem walczących stron, jednak bardzo ważne dla kompleksowego omówienia charakteru wojny. Najważniejszy aspekt stanowi różnica w przygotowaniu obu stron do konfliktu. Wielka Brytania była w okresie wojny imperium światowym, z dostępem do wyszkolonych, dobrze uzbrojonych i wyekwipowanych jednostek. Posiadała infrastrukturę, zaawansowaną technologię, a do swojej dyspozycji miała zarówno jednostki policji, wojska jak i personel medyczny oraz sprawdzone metody łączności. Irlandzcy republikanie musieli natomiast tworzyć swoje zaplecze od podstaw, zapewniając sobie wraz z rozwojem konfliktu źródło dostaw broni, manufaktury produkujące środki wybuchowe, metody transportu, kryjówki oraz, co najważniejsze, metody finansowania tego olbrzymiego wysiłku zbrojnego. Z racji tej dysproporcji oraz z uwagi na wykorzystywane źródła nacisk położony został na opis działań Irlandczyków.

${ }^{2}$ Oscar Traynor - irlandzki polityk i republikanin. Walczył w powstaniu wielkanocnym i w wojnie o niepodległość Irlandii. Podczas wojny domowej działał po stronie antytraktatowej. Minister obrony w latach 1939-1948 i 1951-1961 co czyni go osobą najdłużej pełniącą tę funkcję w historii Irlandii.

${ }^{3}$ Sinn Féin - irlandzka partia polityczna założona w 1905 r. przez Arthura Griffitha. Początkowo w opozycji do idei rządów krajowych w formie promowanej przez Johna Redmonda. Po powstaniu wielkanocnym wielu jej członków poddano represjom, mylnie utożsamiając organizację z Irlandzkimi Ochotnikami odpowiedzialnymi za wybuch powstania.

${ }^{4}$ Zdigitalizowane archiwa dostępne na stronie Biura pod adresem: http://www.bureauofmilitaryhistory.ie/, dostęp: 12.09.2018.

${ }^{5}$ A. Pawłowska, Ewolucja taktyki wojennej Irlandczyków i Brytyjczyków podczas wojny o niepodległość Irlandii w latach 1919-1921, „Acta Universitatis Lodziensis Folia Historica” 2017, nr 98, s. 117-141. 
W części pierwszej omówiony został stan finansów obu stron konfliktu oraz metody pozyskiwania funduszy na prowadzenie wojny. Następnie analizie została poddana kwestia broni palnej poprzez postawienie następujących pytań badawczych: jakie były sposoby pozyskiwania uzbrojenia? Z jakich miejsc je sprowadzano i jakie trasy przerzutu zostały opracowane? Wreszcie: jakie rodzaje broni pozyskiwano? W części trzeciej naświetlona została kwestia użycia środków wybuchowych podczas konfliktu w poszukiwaniu odpowiedzi na pytania: skąd pozyskiwano prefabrykaty do ich produkcji? Czy strona irlandzka dysponowała odpowiednią infrastrukturą i wykwalifikowanymi specjalistami? Jakich materiałów używano i jakie rodzaje środków wybuchowych z nich produkowano? W części czwartej omówione zostały środki transportu używane przez obie strony wraz $\mathrm{z}$ analizą ich wpływu na zmiany w taktyce walki. Kwestie pomocy medycznej, umundurowania i aprowizacji opisane zostały w kolejnym fragmencie po postawieniu następujących pytań badawczych: w jaki sposób udzielano pomocy medycznej walczącym żołnierzom? Czym pod tym względem prowincja różniła się od miasta? Jaka była specyfika irlandzkiego umundurowania? Skąd pozyskiwano żywność i jak jej jakość wpływała na zdrowie żołnierzy? W ostatniej części analizie zostały poddane kryjówki oraz sposoby łączności Irlandzkiej Armii Republikańskiej, ich typologia i znaczenie.

\section{Sposoby finansowania wysiłku zbrojnego}

Bez funduszy nie da się prowadzić wojny. Obie strony konfliktu zdawały sobie z tego sprawę. Wielka Brytania podczas I wojny światowej nie tylko pożyczała duże sumy państwom Ententy, ale również sama zadłużyła się u Stanów Zjednoczonych. Olbrzymie sumy z budżetu pochłaniały odszkodowania i pomoc dla zdemobilizowanych żołnierzy i ich rodzin. Podczas wojny wzrosła produkcja w sektorze zbrojeniowym, ale wszystkie inne gałęzie przemysłu doświadczyły jej wyraźnego spadku. Bezrobocie na początku lat dwudziestych sięgnęło niemal 17\%. Wojna pozbawiła też Wielką Brytanię niektórych rynków zbytu i osłabiła jej imperium kolonialne doprowadzając do spadku eksportu. Dopiero w połowie 1919 r., a więc już po rozpoczęciu konfliktu w Irlandii sytuacja finansowa Brytyjczyków zaczęła się powoli poprawiać. Udało się zmniejszyć deficyt bilansu handlowego. Recesja, która pojawiła się w 1918 r., zakończyła się, a rozpoczął się okres dobrej koniunktury związany ze zwiększonym popytem na artykuły konsumpcyjne, niedostępne podczas wojny ${ }^{6}$. Opinia publiczna w Wielkiej Brytanii naciskała

\footnotetext{
${ }^{6}$ H. Zins, Historia Anglii, Warszawa 1995, s. 325-326.
} 
na szybką demobilizację armii ${ }^{7}$. W tej sytuacji rząd zdecydował o zasileniu topniejących szeregów Królewskiej Policji Irlandzkiej ${ }^{8}$ byłymi żołnierzami. W początkowym etapie wojny nie było możliwe zaangażowanie regularnego brytyjskiego wojska, z powodu pacyfistycznych zapatrywań społeczeństwa, jak i kwestii finansowych.

Sytuacja finansowa Brytyjczyków była daleka od idealnej, ale zdecydowanie lepsza od tej, w której znajdowali się Irlandczycy. Wyspa była uzależniona gospodarczo od Wielkiej Brytanii. Dopiero w trakcie wojny o niepodległość podziemne państwo Irlandzkie zaczęło przejmować struktury administracyjne i niszczyć podatkowe więzi z Imperium. Republikański rząd działał głównie dzięki składkom partyjnym Sinn Féin. Resztę funduszy pozyskiwano na charytatywnych zbiórkach, wykładach i przyjęciach. Sinn Féin wyłożyło 1300 funtów na rozpoczęcie działalności Dáil Éireann9. Finansowo rząd wspierały też rodziny ofiar powstania wielkanocnego oraz osoby zaangażowane w ruch republikański. Przykładowo, Anna O’Rahilly, siostra Michaela $0^{\prime}$ Rahilly $^{10}$, który zginął podczas powstania wielkanocnego, udzieliła rządowi pożyczki w wysokości 2 tys. funtów ${ }^{11}$. Darowizny nie mogły jednak zaspokoić potrzeb rodzącego się państwa podziemnego. Zaczęto, więc organizować oficjalne zbiórki. Podczas trwania kryzysu poborowego stworzono tzw. Fundusz Antykonskrypcyjny. Według raportów Królewskiej Policji Irlandzkiej, 21 tys. funtów, pochodzących z funduszu, zostało przekazanych Komitetowi Mansion House (przyszłemu parlamentowi), a 17 tys. trafiło do partii Sinn Féin ${ }^{12}$.

W pierwszym irlandzkim rządzie ministrem finansów został Eoin Mac$\mathrm{Neill}^{13}$. Funkcję tę sprawował jednak tylko przez 4 miesiące aż do rekon-

7 S.R. Graubard, Military Demobilization in Great Britain Following the First World War, „The Journal of Modern History” 1947, t. 19, nr 4, s. 303.

${ }^{8}$ Królewska Policja Irlandzka (ang. Royal Irish Constabulary, w skrócie RIC) - licząca w tym okresie 9 tys. członków formacja policyjna. Jedna z dwóch istniejących na terenie Irlandii (drugą była Dublińska Policja Metropolitalna funkcjonująca jedynie na terenie Dublina).

${ }^{9}$ Dáil Éireann - obecnie izba niższa irlandzkiego parlamentu. W okresie, na którym skupia się niniejsza praca, parlament irlandzki był jednoizbowy, stąd sformułowanie stosowane jest tu wymiennie z tym terminem. Izba wyższa irlandzkiego parlamentu Seanad Éireann została ustanowiona dopiero w 1922 r. i od tego czasu tworzy wraz z Dáil Éireann dwuizbowy parlament określany mianem Oireachtas.

${ }^{10}$ Michaela O’Rahilly - irlandzki republikanin, współzałożyciel organizacji Irlandzkich Ochotników.

${ }^{11}$ G. Evans, The raising of the first internal Dáil Éireann Loan and the British responses to it, 1919-1921 (Praca magisterska obroniona w 2012 r. na Uniwersytecie w Maynooth), s. 31-32, http://eprints. maynoothuniversity.ie/4012/1/MLitt_-_Gary_Evans.pdf, dostęp: 12.09.2018.

12 Ibidem, s. 31.

${ }^{13}$ Eoin MacNeill - irlandzki badacz, nacjonalista, polityk partii Sinn Féin, szef sztabu Irlandzkich Ochotników w chwili wybuchu powstania wielkanocnego; zdecydowanie prze- 
strukcji gabinetu w kwietniu 1919 r., kiedy ministerstwo to przejął Michael Collins ${ }^{14}$. Następnego dnia rada ministrów udzieliła mu specjalnych pełnomocnictw.

Tymczasem w świetle wyjątkowo dużego budżetu potrzebnego w tej chwili oraz niemożności określenia niezwykłych wydatków, których można się spodziewać tej wiosny i lata, Minister Finansów zostaje niniejszym upoważniony do nieodwoływania się do Dáilu by dostać fundusze pozyskane w wyniku zbiórki Antykonskrypcyjnej, obligacji republikańskich i innych źródeł finansowania, oraz do zastosowania owych środków do celów, które ministerstwo (w liczbie nie mniejszej niż 5 osób) jednogłośnie uzna za stosowne ${ }^{15}$.

Pełnomocnictwa te wzmocniły pozycję Collinsa względem innych ministró $w^{16}$, ale także nałożyły na jego barki odpowiedzialność za pozyskanie funduszy na cele wojenne oraz zarządzanie wieloma przedsięwzięciami finansowymi założonymi w tym celu. Arthur Mitchell oszacował, że irlandzki rząd potrzebował 25 tysięcy funtów rocznie, by finansować operacje w takim kształcie, jaki miały one w 1919 r. ${ }^{17}$ Sukces lub porażka operacji finansowych ministerstwa mogły zadecydować o triumfie lub klęsce idei republiki.

$\mathrm{Na}$ wiosnę 1919 r. przygotowano plan wypuszczenia wartych 500 tys. funtów obligacji. Połowa z nich miała zostać sprzedana na terenie kraju, a połowa za granicami. Operacją na wyspie miał zajmować się Collins, natomiast pozyskiwaniem funduszy na terenie USA premier Eamon de Valera ${ }^{18}$

Zakupu można było dokonać w nominałach 1, 5, 10, 20, 50 i 100 funtów. Obligacje były oprocentowane na 5\% w skali roku. Procent miał być naliczany od momentu uiszczenia opłaty, a wypłacany po uzyskania przez Republikę Irlandii uznania międzynarodowego i ewakuacji wojsk brytyjskich z wyspy ${ }^{19}$.

ciwny insurekcji. Minister przemysłu w latach 1919-1921, później minister edukacji Wolnego Państwa Irlandzkiego.

${ }^{14}$ Michael Collins - irlandzki polityk, nacjonalista i republikanin, uczestnik powstania wielkanocnego, członek irlandzkiego parlamentu, minister spraw wewnętrznych i finansów w trakcie wojny o niepodległość. Szef irlandzkiego wywiadu. Sygnatariusz anglo-irlandzkiego traktatu kończącego wojnę, przywódca strony pro-traktatowej podczas wojny domowej.

${ }^{15}$ Stenogram debat Dáilu z dnia 2 kwietnia 1919 r. Propozycje finansowe, http://oire achtasdebates.oireachtas.ie/debates\%20authoring/debateswebpack.nsf/takes/dail191904 0200022?opendocument, dostęp: 12.09.2018.

${ }^{16}$ Do dziś w Republice Irlandii minister finansów ma specjalne miejsce w tradycji parlamentarnej, zwyczajowo uznaje się, że jest to ministerstwo, którego sprawowanie ułatwia później objęcie urzędu premiera.

17 A. Mitchell, Revolutionary Government in Ireland: Dáil Éireann, 1919-'22, Dublin 1995, s. 58.

${ }^{18}$ Eamon de Valera - irlandzki polityk, jeden z przywódców powstania wielkanocnego, Príomh Aire (pierwszy minister, prezydent Dáil Éireann) w czasie wojny o niepodległość. Przeciwnik anglo-irlandzkiego traktatu i przywódca strony antytraktatowej w wojnie domowej. Później Taoiseach (premier) i Uachtarán na hÉireann (prezydent) Republiki Irlandii.

${ }^{19}$ G. Evans, op. cit., s. 34. 
Zbiórkę przeprowadzano okręgami wyborczymi. Collins zalecił szukanie finansowego wsparcia szczególnie pośród ludzi niezwiązanych dotąd z Sinn Féin. Zaznaczył również, że wiele sprzedanych obligacji o małych, np. jedno funtowych, nominałach będzie działało tak samo dobrze jak niewielka liczba sprzedanych dużych nominałów ${ }^{20}$. Sukces zbiórki, podobnie jak wygrana w wyborach partii Sinn Féin został osiągnięty poprzez dobrze zorganizowane struktury terenowe republikanów. W rozprowadzaniu obligacji brały udział wszystkie klasy społeczne. Na listach osób związanych ze zbiórką znaleźli się, zarówno lekarze, nauczyciele, politycy, jak i budowlańcy i właściciele drobnych przedsiębiorstw ${ }^{21}$. Towarzyszyła temu akcja propagandowa. Stworzono m.in. film pokazujący ministra finansów, dokonującego przed Szkołą św. Endy ${ }^{22}$ sprzedaży obligacji ważnym osobistościom związanym z irlandzkim ruchem niepodległościowym np. Norze Connolly - córce James'a Connolly'ego ${ }^{23}$ czy Arthurowi Griffthowi ${ }^{24}$, przywódcy partii Sinn Féin. Materiał filmowy, został rozpropagowany w Ameryce i Australii. Harry Boland $^{25}$, przebywający w tym czasie w Ameryce i tam doglądający wraz z premierem sprzedaży obligacji w liście do Collinsa napisał:

Ten film z tobą i Hegartym sprzedającym obligacje sprawił, że popłakałem się ze śmiechu. Kurczę, chłopie, ale z ciebie aktor. Nikt nie mógł się oprzeć kupowaniu obligacji, mamy tak przystojnego ministra finansó $\mathrm{w}^{26}$.

Zbiórkę pieniędzy na terenie Irlandii zakończono 31 lipca 1920 r. Łącznie zebrano 371,849 funtów. Najwięcej obligacji sprzedano na terenach wiejskich oraz na południu i wschodzie Wyspy. Biorąc pod uwagę stan materialny obywateli Irlandii w tym okresie, zrealizowanie celu zbiórki było wielkim wyczynem ${ }^{27}$. Obligacje sprzedawane w USA dotarły do Irlandii dopiero w 1921 r. Zysk z ich sprzedaży przewyższył jednak wszelkie oczekiwania, osiągając wartość 5.123 .640 dolarów amerykańskich ${ }^{28}$.

${ }^{20}$ Ibidem, s. 42.

${ }^{21}$ Ibidem, s. 46.

22 Założoną przez przywódcę powstania wielkanocnego Pádraiga Pearse’a.

${ }^{23}$ James Connolly - irlandzki polityk, socjalista, przywódca Irlandzkiej Partii Socjalistycznej, jeden z przywódców powstania wielkanocnego, zginął rozstrzelany przez Brytyjczyków po klęsce powstania.

${ }^{24}$ Arthur Griffith - irlandzki polityk, współzałożyciel partii Sinn Féin.

${ }^{25}$ Harry Boland - irlandzki polityk, republikanin, Teachta Dála (członek parlamentu Irlandii) w latach 1918-1922, brał udział w powstaniu wielkanocnym, bliski przyjaciel Michaela Collinsa, późniejszy przeciwnik Traktatu, zginął podczas wojny domowej w $1922 \mathrm{r}$.

${ }^{26}$ G. Evans, op. cit., s. 60.

27 Ibidem, s. 72.

${ }^{28}$ M.F. Carroll, Money for Ireland: Finance, Diplomacy, Politics, and the First Dáil Éireann Loans, 1919-1936, Westport 2002, s. 23. 
Zebrane pieniądze przeznaczono na różnorodne cele. Priorytetem było zaopatrzenie rodzącej się Irlandzkiej Armii Republikańskiej w broń, fundusze potrzebne były również na wspomaganie rodzin żołnierzy poległych w walce, kryjówki, materiały do produkcji środków wybuchowych oraz finansowanie działalności irlandzkiego państwa podziemnego.

\section{Metody pozyskiwania broni i jej rodzaje}

Walki rozpoczęły się zanim irlandzki rząd pozyskał całość funduszy z narodowych obligacji. Irlandzka Armia Republikańska potrzebowała broni. Już od 1918 r. przeprowadzane były akcje w celu jej pozyskania. Najpopularniejszą metodą były napady na koszary, posterunki policji lub domy prywatne, również na terenie Wielkiej Brytanii ${ }^{29}$. Warto przy tym zaznaczyć, że IRA konfiskowała również broń katolikom, jeśli z własnej woli nie przekazali jej siłom republikańskim ${ }^{30}$. Takich sytuacji było jednak niewiele. Ludność popierająca sprawę republikańską sama przekazywała Ochotnikom uzbrojenie ${ }^{31}$. Często było ono jednak przestarzałe lub niesprawne.

Metoda pozyskiwania wyposażenia poprzez napady była wysoce nieskuteczna, poszczególne komisariaty, koszary i domy prywatne nie dysponowały jej dużą ilością. Oprócz tego uprawiającym ten proceder groziła kara do 12 miesięcy pozbawienia wolności ${ }^{32}$. Duża ilość pozyskanej broni była szybko tracona przez IRA w wyniku policyjnych akcji i nalotów ${ }^{33}$. Nie istnieją dane na temat liczby broni zarekwirowanej na całym terytorium Irlandii, ale dostępne są informacje o Dublinie, centrum walk, z którego broń przekazywano często innym ośrodkom. W 1920 r. policja skonfiskowała ponad 400 rewolwerów oraz 200 karabinów i strzelb, oprócz tego 1000 granatów oraz 30 tys. sztuk amunicji ${ }^{34}$. W przypadku regularnej wojny takie braki w wyposażeniu oznaczałyby klęskę, jednak specyfika walk w pierwszej fazie wojny sprawiła, iż Armia Republikańska mogła realizować swoje cele z bardzo małym arsenałem.

${ }^{29}$ BMH.WS0828, s. 5, http://www.bureauofmilitaryhistory.ie/reels/bmh/BMH.WS0828.pdf, dostęp: 12.09.2018. W dalszej części pracy dla ułatwienia w przypisach podawana będzie jedynie sygnatura dokumentu oraz strona.

30 BMH.WS0519, s. 5.

31 C. Townshend, The Republic: The Fight For Irish Independence, London 2013, s. 123.

32 BMH.WS0519, s. 6.

${ }^{33}$ G. Pattison, The British Army's Effectiveness in the Irish Campaign 1919-1921 and the Lessons for Modern Counterinsurgency Operations, with Special Reference to C3I Aspects, materiały Cornwallis XIV: Analysis of Societal Conflict and Counter-Insurgency, s. 11, http://www.ismor. com/cornwallis/cornwallis_2009/6-Pattison-CXIV.pdf, dostęp: 12.09.2018.

${ }^{34}$ G. Pattison, op. cit., s. 11. 
Jedynym opłacalnym źródłem broni były dostawy dla Ochotników Ulsterskich $^{35}$. George Fitzgerlad, członek I brygady dublińskiej w swoich wspomnieniach opisywał jeden z przechwyconych ładunków:

Kiedy tam dotarliśmy, zaczęliśmy opróżniać worki z owsem i wyjmować z nich woreczki z amunicją. Choć pracowaliśmy całą noc, nie byliśmy w stanie opróżnić wszystkich i pozyskano tylko część amunicji ${ }^{36}$.

Lojaliści dysponowali większą ilością broni, mogli również dozbrajać się nie obawiając się interwencji policji. Od początku wojny można było zaobserwować efekt eskalacji. Republikanie napadali na domy unionistów, by zdobyć broń, lojaliści, by ochraniać się przed nimi zaopatrywali się w większą ilość broni. Wrogość narastała ${ }^{37}$.

Koniec Wielkiej Wojny oznaczał dużą ilość uzbrojenia na rynku, nie tylko na terenie Wielkiej Brytanii, ale również w Europie ${ }^{38}$. Analiza materiałów Biura Historii Militarnej dostarcza informacje o zróżnicowanych źródłach jej pozyskiwania. Wyszczególnić można 4 duże punkty zdobywania i przerzutu broni na terenie Wielkiej Brytanii oraz kilka poza jej granicami.

Jednym z najważniejszych źródeł zaopatrzenia była Szkocja. W jej industrialnej stolicy - Glasgow egzystowała duża irlandzka diaspora, chętna do pomocy w republikańskiej sprawie. Struktury Irlandzkiego Bractwa Republikańskiego były tam wyjątkowo silne. Broń pozyskiwano w sposób legalny, drogą zakupu, a następnie drobnymi partiami transportowano do Liverpoolu pociągiem, zazwyczaj w zwykłych torbach podróżnych ${ }^{39}$, gdzie następnie pozostawiano ją dla grupy zajmującej się wysyłką dostaw z Liverpoolu do Dublina. Takie rozwiązanie było jednak ryzykowne. James Byrne, członek Irlandzkiego Bractwa Republikańskiego ${ }^{40}$ opisuje w swoich zeznaniach takie wydarzenie:

Naczelnik stacji był podejrzliwy względem pudełka oraz jego zawartości i zawiadomił policję. Przyszli i otworzyli pudło, wyjęli z niego zawartość, a następnie wypełnili je cegłami, po czym wysłali je do Dublina na oryginalny adres ${ }^{41}$.

35 Ochotnicy Ulsterscy - ang. Ulster Volunteers (nie mylić z Ulster Volunteer Force) - lojalistyczna organizacja paramilitarna stworzona w 1912 r. by sprzeciwić się przyznaniu Irlandii autonomii (ang. Home Rule).

${ }^{36}$ BMH.WS0684, s. 7.

37 R.B. McDowell, Crisis and Decline: The Fate of the Southern Unionists, Dublin 1997, s. 191.

38 P. Cottrell, The Anglo-Irish War. The Troubles of 1913 -1922, Oxford 2006, s. 42.

${ }^{39}$ BMH.WS0777, s. 3.

${ }^{40}$ Irlandzkie Bractwo Republikańskie - organizacja siostrzana Bractwa Feniańskiego, tajne stowarzyszenie istniejące od połowy XIX w., którego głównym celem było wyzwolenie Irlandii spod władzy Wielkiej Brytanii.

${ }^{41}$ BMH.WS0828, s. 6. 
Policja w Szkocji zdawała sobie sprawę z tego procederu. Brak było jednak twardych dowodów przeciw członkom IRB. Dopiero w 1921 r., gdy walka brytyjskich sił z irlandzką partyzantką osiągnęła apogeum, stróżom prawa udało się aresztować osoby związane z przemytem ${ }^{42}$. Nawet wtedy jednak procederu nie udało się powstrzymać. Jedynie modus operandi Irlandczyków uległ zmianie. Zrezygnowano z drogi kolejowej. Broń do Liverpoolu zaczęto transportować ciężarówkami ${ }^{43}$. Niewątpliwie najbardziej oryginalną metodę przerzutu prezentował Henry Cole, którego zwyczajem było podróżowanie z Glasgow do Liverpoolu z torbą golfową wypełnioną lufami karabinów, do których doczepiał końcówki kijów golfowych. Oddzielone od luf kolby były natomiast transportowane przez jego kolegę $\mathrm{w}$ walizce. $\mathrm{W}$ ten sposób nie zwracali na siebie uwagi jako golfista podróżujący na rozgrywki oraz jego służący, niosący bagaż $\mathrm{e}^{44}$.

Kolejnym ważnym industrialnym ośrodkiem był Manchester, również wypełniony pracującymi z dala od domu Irlandczykami. Dużą rolę w pozyskiwaniu uzbrojenia odgrywały tam osobistości ze świata przestępczego. Kapitan Thomas Young, późniejszy inspektor do spraw uzbrojenia podaje pseudonimy dwóch takich osobistości. Niejakiego „Papieża” oraz „Ojca Petera" przy czym zaznacza, że żaden z nich nie miał nic wspólnego ze stanem duchownym. Ten rodzaj przydomków mógł wskazywać natomiast na ich wyznanie i pochodzenie. Obaj w dużym stopniu przyczynili się do sprawnego zaopatrywania Republikanów w broń ${ }^{45}$. Ilość pozyskanej tam broni była tak duża, że nie było jej gdzie składowaćt ${ }^{4}$. Transport do Liverpoolu przeprowadzano najczęściej ciężarówkami. Mniejsze ilości przemycały pojedyncze osoby. Teresa McGeehan, pochodząca z Donegal pracująca w Bankowej Spółce Manchesteru regularnie przemycała w swojej walizce broń przy okazji odwiedzin w rodzinnych stronach ${ }^{47}$.

Kolejnym ośrodkiem, z którego Irlandczycy pozyskiwali zaopatrzenie było samo centrum Imperium - Londyn. Tam również skontaktowano się z przedstawicielami półświatka. Pośrednikami w tych kontaktach zostali byli irlandzcy stróże prawa, wydaleni ze służby z powodu uczestnictwa w strajku.

Skontaktowali mnie z Irlandczykiem z Londynu, bukmacherem o nazwisku Conroy, który mógłby załatwić broń do kupienia. Poprzez Conroya

\footnotetext{
${ }^{42}$ BMH.WS0776, s. 4.

${ }^{43}$ Ibidem, s. 6.

${ }^{44}$ BMH.WS0776, s. 6.

45 BMH.WS0531, s. 8.

46 BMH.WS0847, s. 13.

47 BMH.WS0531, s. 8.
} 
skontaktowałem się z Żydem o nazwisku Ginger Barnett z Petticoat Lane na East Endzie i mieszańcem nazywanym Darbym Czarnuchem ${ }^{48}$. Tego ostatniego mogę tylko określić jako przywódcę gangu. Tymczasem Tom Treacy przysłał mi 100 funtów na rozruch. Z pomocą Barnetta i Darby'ego Czarnucha udało mi się zakupić mniej więcej 2-3 rewolwery albo automaty tygodniowo. Czasami sprzedawali mi je bezpośrednio, ale zazwyczaj odwiedzałem z którymś z nich kwatery dla marynarzy na Petticoat Lane, Limehouse Causeway i Pennyfields (w dzielnicy Chińczyków) oraz murzyński hotel na Cable S. w East Endzie. Marynarze, których tam spotykałem byli moim głównym źródłem zaopatrzenia i płaciłem im od 2 do 4 funtów za rewolwer, zależnie od rozmiaru i stanu ${ }^{49}$.

Broń pozyskaną w Londynie przesyłano drogą pocztową do Irlandii. Pojedyncze sztuki owijano w watolinę i wysyłano na fikcyjny adres w Killkenny gdzie następnie za pośrednictwem szefa poczty trafiała do dowództwa IRA w okręgu ${ }^{50}$.

Oprócz źródeł w Wielkiej Brytanii uzbrojenie pozyskiwano też poza jej granicami. W Europie, jednym z głównych ośrodków była Republika Weimarska, skąd Irlandczycy pozyskiwali bardziej zaawansowaną technologicznie broń, np. pistolety maszynowe, w cenie 250 marek za sztukę. Broń była następnie transportowana drogą morską do Wielkiej Brytanii ${ }^{51}$.

W zeznaniach republikanów często pojawia się plan sprowadzenia broni z Włoch. Wspominają o tym m.in. Florence O’Donoghue, Patric O’Driscoll czy Liam O’Brian. Karabiny i pistolety maszynowe miały zostać przekazane republikanom przez włoską policję. W oficjalnym raporcie miała się znaleźć informacja, że broń została zużyta i trafiła na złom. W rzeczywistości broń była zupełnie nowa. Następnie ładunek drogą morską miał trafić bezpośrednio do wybrzeży Irlandii. W celu jego odbioru IRA próbowała zrekrutować w swoje szeregi doświadczonych żeglarzy ${ }^{52}$. Osoby odpowiedzialne za kontakt ze stroną włoską zostały jednak aresztowane. Ze szczątkowej informacji w zeznaniu Florence’a O’Donoghue można wywnioskować, że broń nigdy nie dotarła jednak do brzegów zielonej wyspy ${ }^{53}$.

Największym, niewyczerpanym źródłem zaopatrzenia dla IRA były Stany Zjednoczone. W USA od 100 lat działała organizacja Clan na Gael ${ }^{54}$, zrzesza-

${ }^{48}$ W źródle pojawiają się pejoratywne i rasistowskie, angielskie określenia „a half-cast” $i$ „Darby the Coon".

${ }^{49}$ BMH.WS1360, s. 2.

${ }^{50}$ Ibidem.

51 Ibidem, s. 4.

${ }^{52}$ BMH.WS0554, s. 2.

${ }^{53}$ Ibidem, s. 4.

${ }^{54}$ Clan na Gael - irlandzka organizacja republikańska, działająca w Stanach Zjednoczonych Ameryki od XIX w. Organizacja siostrzana Irlandzkiego Bractwa Republikańskiego. 
jąca amerykanów irlandzkiego pochodzenia. Ponadto od 1919 r. przebywał tam premier De Valera, pozyskujący fundusze na działalność republikańską wraz z Harrym Bollandem. Dowództwo IRA w Irlandii oddelegowało kilku żołnierzy do zadania sprowadzania broni. Ich działania w swoich zeznaniach opisywał Edmond O’Brien, członek Irlandzkich Ochotników z Gallbaly od początku 1920 r. działający na terenie USA.

Działacze Irlandzcy w Ameryce kompletowali dostawy broni z różnych źródeł, duża część pozyskiwana była od prywatnych darczyńców, przekazujących republikanom swoje prywatne kolekcje, lub czyniących $\mathrm{w}$ ich imieniu olbrzymie zamówienia $w$ fabrykach broni i amunicji ${ }^{55}$. Siedzibą główną Towarzystwa Pożyczki Narodowej był Nowy Jork, jednak dostawy pozyskiwano również na prowincji56. Proceder, tylko częściowo legalny, był ochraniany przez amerykańskich policjantów irlandzkiego pochodzenia. O’Brienowi podczas kolekcjonowania dostaw towarzyszył zaufany policjant nazwiskiem Lynch, ochraniający go. Dzięki niemu republikanin mógł również przechodzić przez kordony policyjne (częste w objętej prohibicją Ameryce). Wystarczyło, że Lynch nałożył mu na nadgarstki kajdanki i udawał, że go aresztował ${ }^{57}$.

Kontakty Clan na Gael z policją sięgały wysoko. O’Brien opisywał również sytuację, w której podróżując z ładunkiem broni, bez ochrony irlandzkiego policjanta, został zatrzymany, przeszukany i aresztowany po odkryciu natury jego ładunku, przez dwóch funkcjonariuszy. Wydarzenie miało miejsce w Irlandzkiej dzielnicy Nowego Jorku. Członek Clan na Gael, będący świadkiem zdarzenia poinformował o nim Harry'ego Bollanda, ten z kolei skontaktował się z policyjnymi oficjelami.

Zapomniałem jakie postawiono nam zarzuty, ale było to coś pospolitego. Zasądzono nam grzywnę w wysokości dolara na łebka i natychmiast wypuszczono. Po procesie wyszliśmy bocznymi drzwiami i napotkaliśmy kilku policjantów, którzy przeprosili nas za ten incydent. Byli bardzo poirytowani, ze coś takiego miało miejsce i winili młodego polskiego oficera, lub „polaczka” jak go nazywali, za to że - jak to ujęli - wsadzał nos w nie swoje sprawy. Kazali nam zadzwonić wieczorem by odzyskać ładunek; dali nam numer telefonu, żebyśmy mogli ich uprzedzić, by przygotowali paczki do naszego przyjazdu ${ }^{58}$.

\footnotetext{
55 BMH.WS0597, s. 46.

${ }^{56}$ Ibidem.

57 Ibidem, s. 47.

58 Ibidem, s. 50-52.
} 
Na broń przemycaną ze Stanów składały się głównie rewolwery Webley i Smith\&Wesson kaliber 45, a także Mausery C $96^{59}$. Przemycano również pistolety maszynowe Thompson w niewielkiej ilości oraz amunicję ${ }^{60}$. Zebrane zaopatrzenie przechowywano w Kościele Karmelitów ${ }^{61}$, a następnie dzielono na małe zestawy i wysyłano na pokładach statków handlowych do Liverpoolu, po przekupieniu kapitanów, załogi oraz urzędników portowych ${ }^{62}$.

Pozostałymi ośrodkami, z których sprowadzano broń, choć w znacznie mniejszych ilościach były: Buenos Aires i Antwerpia ${ }^{63}$.

Większość tras przemytu broni prowadziła do Liverpoolu. Jako drugi po Londynie ośrodek portowy w Wielkiej Brytanii, stanowił on węzeł komunikacyjny nie tylko na drodze z Europy i Ameryki, ale również dla przemytu pochodzącego z samego Imperium ${ }^{64}$. Podobnie jak inne ośrodki na terenie Zjednoczonego Królestwa był on wypełniony podążającymi za pracą Irlandczykami i łatwo było znaleźć pomoc przy przerzucie ładunków. Po przewiezieniu do miasta dostawy ukrywano w domach sympatyków sprawy irlandzkiej ${ }^{65}$. Następnie dzielono na mniejsze części i ukrywano w marynarskich workach. By uniknąć przeszukania, irlandzcy marynarze zjawiali się na pokładzie wczesnym rankiem, zanim urzędnicy portowi stawili się jeszcze do pracy ${ }^{66}$. Broń była następnie odbierana w Dublinie, gdzie w dokach IRA miała swoich ludzi, oddelegowanych w celu odbioru „przesyłek”.

\section{Wytwarzanie i wykorzystywanie środków wybuchowych}

Materiały wybuchowe znalazły szerokie zastosowanie w konflikcie anglo-irlandzkim. Szczególne umiłowanie do tego rodzaju broni wykazywała strona irlandzka. Brytyjczycy stosowali je w bardzo ograniczonej formie: granatów nasadkowych i tzw. Bomb Millsa (wspólna nazwa brytyjskich granatów obronnych, stosowanych od 1915 r.). Winston Churchill ${ }^{67}$ w swojej późniejszej korespondencji z Michaelem Collinsem wyrażał opinię, iż gra-

${ }^{99}$ Nazywane przez Irlandczyków „Piotrami malarzami” - od imienia i przydomku łotewskiego gangstera z East Endu słynącego z używania tego rodzaju broni.

60 BMH.WS0597, s. 48.

${ }^{61}$ Ibidem, s. 45.

62 Ibidem, s. 49.

${ }^{63}$ BMH.WS0814, s. 11.

${ }^{64}$ BMH.WS0814, s. 3.

${ }^{65}$ Ibidem, s. 2.

${ }^{66}$ Ibidem, s. 7.

${ }^{67}$ Winston Leonard Spencer Churchill - brytyjski polityk, strateg, pisarz i historyk, dwukrotny premier Zjednoczonego Królestwa, laureat literackiej Nagrody Nobla. W latach 1911-1915 I Lord Admiralicji, gabinecie Lloyda George’a pełnił funkcje: ministra uzbrojenia, ministra wojny, ministra lotnictwa i sekretarza stanu do spraw kolonii. 
naty i środki wybuchowe są bronią rewolucjonistów, a nie rządu, a w przypadku gdyby wpadły w niepowołane ręce mogą wyrządzić niepowetowane szkody ${ }^{68}$. Irlandczycy natomiast opierali dużą część swojego wysiłku zbrojnego na wykorzystywaniu substancji wybuchowych. Wytwarzano z nich granaty (również odłamkowe), bomby, miny oraz substancje zapalające ${ }^{69}$.

Proces wytwarzania środków wybuchowych był niezwykle skomplikowany. Podstawowym problemem, z jakim mierzyła się Irlandzka Armia Republikańska, był trudny dostęp do prefabrykatów do ich produkcji. Od $1920 \mathrm{r}$. dostęp do nich był ograniczony i ściśle kontrolowany, co zmuszało Irlandczyków do poszukiwań innych źródeł ich pozyskiwania ${ }^{70}$. Dodatkowo Irlandia nie posiadała własnego przemysłu petrochemicznego, co oznaczało nie tylko braki w materiałach wybuchowych, ale i mniejszą liczbę wykształconych specjalistów, którzy mogliby zająć się produkcją tego rodzaju broni ${ }^{71}$.

Jednym z głównych źródeł pozyskiwania prefabrykatów były kopalnie. Ich liczba była jednak ograniczona, a w późniejszych etapach wojny objęto je dodatkową ochroną. Podobnie jak w przypadku broni palnej źródeł pozyskiwania materiałów zaczęto poszukiwać poza wyspą. Doskonałym miejscem do tego rodzaju aktywności była Szkocja ${ }^{72}$. Z tamtejszych kopalń pozyskiwano potrzebne materiały drogą kupna lub kradzieży ${ }^{73}$. Tutaj również głównym punktem przerzutu przemycanych środków był Liverpool ${ }^{74}$, skąd wysyłano do Irlandii chemikalia oznakowane jako skrzynie z masłem ${ }^{75}$. Materiały kupowano również w granicach Wielkiej Brytanii, od zaprzyjaźnionych producentów, przykładem może być tu fabryka Fitzgeralda w Greenwich ${ }^{76}$.

Szefem departamentu chemikaliów i amunicji IRA w latach 1917-1920 był James O’Donovan, doktorant Uniwersytetu w Dublinie i były pracownik fabryki środków wybuchowych Nobla. Choć jego krewni otwarcie wspierali ruch republikański, O'Donovan pozostawał poza podejrzeniem, utrzymując opinię jedynego poważnego i szanowanego członka rodziny. Najważniejszym zadaniem O’Donovana było opracowanie formuły, wymagającej użycia składników łatwo dostępnych dla członków IRA oraz możliwie jak najbezpieczniejszej, tak by nawet niewykształceni żołnierze, przy zachowaniu

${ }_{68}$ J.M. Regan, Myth and the Irish State, Newbridge 2013, s. 659.

${ }^{69}$ W.H. Kautt, Ambushes and Armour: The Irish Rebellion 1919-1921, Newbridge 2010, s. $164-179$.

${ }^{70}$ BMH.WS1713, s. 7.

${ }^{71}$ BMH.WS1713, s. 8.

72 BMH.WS0814, s. 1.

${ }^{73}$ BMH.WS0777, s. 4.

${ }^{74}$ BMH.WS1713, s. 8.

75 BMH.WS1507, s. 2.

${ }^{76}$ BMH.WS1713, s. 8-9. 
podstawowych środków bezpieczeństwa, mogli je produkować. Jak sam wspominał: Musiały być w miarę idiotoodporne, bo nie mogliśmy dopuścić do sytuacji, w której przypadkiem wysadzaliby się ludzie w całym kraju ${ }^{77}$.

Początkowo głównym składnikiem środków wybuchowych był gelignite ${ }^{78}$, wykorzystywany przez Irlandczyków już podczas Powstania. W niskiej temperaturze wytrącają się z niego kryształki, które czynią substancje wysoce niestabilną ${ }^{79}$. Opracowano też substancję wybuchową określaną mianem „mąki wojennej”. Była to żywica poddawana reakcji z kwasem azotowym. Proces jej wytwarzania był skomplikowany, po przereagowaniu należało wypłukać kwas azotowy. Przy nieumiejętnym wykonaniu tej czynności istniało zagrożenie pozostawienia małych ilości kwasu w składzie, co zwiększało niestabilność substancji i ryzyko wypadku ${ }^{80}$. Kolejnymi substancjami były azotan amonu i azotan aluminium, jednak nie były one używane w szerokiej produkcji. O’Donovan cały czas pracował nad bezpieczniejszym środkiem. Efektem jego starań było opracowanie tzw. „irlandzkiego cheddara” - substancji wybuchowej opartej na szedycie ${ }^{81}$. Oprócz substancji wybuchowych do wytwarzania granatów potrzebny był również koks odlewniczy, masa formierska, metal pozyskiwany ze złomowisk oraz surówka metalowa, z których wytwarzano obudowy granatów.

Początkowo eksperymenty przeprowadzano w laboratoriach Uniwersytetu Dublińskiego, gdzie jako doktorant pracował O’Donovan. Dwóch pracowników wiedziało o tym procederze. Był to profesor nadzorujący pracę naukowca oraz nadzorca laboratorium, który był świadkiem wypadku O’Donovana podczas pracy z ciekłą formą gazu bojowego. Żaden z nich nie ujawnił informacji policji ${ }^{82}$. Również specjalistyczne narzędzia, odczynniki i inne potrzebne utensylia pozyskiwane były z Kolegium Nauk Ścisłych w Dublinie. Schemat budowy granatu wykorzystywany początkowo w manufakturach IRA został opracowany przez członka loży oranżystów ${ }^{83}$

77 Ibidem, s. 5.

${ }^{78}$ Żelatyna wybuchowa - materiał wybuchowy będący 10 procentową mieszaniną azotanu celulozy z nitrogliceryną. W temperaturze pokojowej jest żelem o barwie żółtej - M. Korzun, 1000 słów o materiałach wybuchowych i wybuchu, Warszawa 1986, s. 268.

${ }^{79}$ BMH.WS1713, s. 11.

${ }^{80}$ BMH.WS1713, s. 6.

${ }^{81}$ Ibidem, s. 13.

${ }^{82}$ Ibidem, s. 6.

${ }^{83}$ Orange Order - organizacja założona w 1795 r. w celu przeciwdziałania emancypacji irlandzkich katolików, wzorowana na masonerii, zorganizowana na kształt zakonu. W początkowym okresie działalności miała charakter tajny. Nazwa nawiązuje do króla Wilhelma III Orańskiego, który zdetronizował ostatniego katolickiego króla Anglii - Jakuba II Stuarta. Członkowie organizacji zwani są oranżystami, muszą być protestantami i nie mogą pozostawać w związku małżeńskim z katolikiem. Zakon zrzesza zwolenników unii Irlandii z Wielką Brytanią. 
- studenta, który był przekonany, że wykonuje pracę zaliczeniową dla swojego wykładowcy ${ }^{84}$. Zapotrzebowanie na granaty wzrastało, potrzebne było stworzenie manufaktur, które stale dostarczałyby zaopatrzenie dla IRA. W samym Dublinie było ich kilka.

Jednym z najważniejszych punktów produkcji była fabryka umieszczona w piwnicy sklepu z rowerami Heron and Lewless pod numerem 198 na Parnell Street w Dublinie ${ }^{85}$. Miejsce to zostało ocenione przez dowództwo jako idealne. Na parterze znajdywał się sklep, w którym przyjmowano klientów i dokonywano sprzedaży. Na piętrze znajdował się warsztat, gdzie dokonywano naprawy jednośladów. Jego okna wychodziły na ulicę, co pozwalało monitorować, kto zbliża się do sklepu. W piwnicy natomiast było wystarczająco dużo miejsca, by rozpocząć tam produkcję uzbrojenia. Wprowadzono też prosty system sygnalizacji zagrożenia. Na parterze, w części właściwej sklepu ulokowany był włącznik światła połączony z żarówką w piwnicy. W przypadku zagrożenia pracownik sklepu sygnalizował je żołnierzom pracującym piętro niżej. Wszelkie przedmioty powiązane z nielegalną produkcją znikały w przeciągu kilku minut $\mathrm{z}$ widoku ${ }^{86}$. Produkcję udawało się utrzymywać w sekrecie. Jak opisuje Patric McHugh, pracownik manufaktury:

Przy odlewaniu mosiądzu wydziela się dużo białych oparów, w związku z czym trzeba było zawsze mieć otwarte okna przy chodniku, by opary miały ujście. Parnell Street pokrywające się białą chmurą stało się tak regularnym zjawiskiem, że nikt nie zwracał na to uwagi, oprócz stwierdzeń, że Heron \& Lawless znów pracuje. Nikt nigdy nie próbował wezwać straży pożarnej, po ujrzeniu oparów uciekających z piwnicy ${ }^{87}$.

Co ciekawe, to nie oczywiste dowody produkcji przemysłowej zwróciły uwagę stróżów prawa na sklep przy Parnell Street, a kradziony rower, który został „pozyskany” przez IRA podczas jednego z rajdów, a następnie przydzielony jednemu z pracowników fabryki, Thomasowi Youngowi. Zaobserwowawszy jednoślad, dwaj konstable zaczęli wypytywać Younga o źródło jego pochodzenia Nie miałem na niego paragonu i musiałem wymyślić historyjke o tym, jak kupiłem go od pewnego gościa, który wyjechał do Glasgow itd., itp. Historyjka ta, jak i sam warsztat, wzbudziły podejrzenia policjantów, ale nie znaleźli oni żadnych dowodów popełnienia przestępstwa. Przez następny rok stróże prawa regularnie natykali się na Younga w podejrzanych sytuacjach, ale nigdy nie mogli go połączyć bezpośrednio z czynem zabronionym. Ostatecznie ich frustracja uratowała Younga.

\footnotetext{
${ }^{84}$ BMH.WS0531, s. 10-11.

85 Ibidem, s. 9.

${ }^{86}$ BMH.WS0531, s. 12.

${ }^{87}$ BMH.WS0664, s. 6.
} 
Kilka dni po ostatnim nalocie w grudniu 1920 roku wpadłem na obu na South Great George's Street. Oczywiście rozpoznali mnie. Wiedzieli, że trwają gorączkowe poszukiwania członków departamentu broni i uzbrojenia prowadzone przez Czarno-Brunatnych, policję i wojsko. Zatrzymali mnie i jeden z nich powiedział ,!!! mać, znowu ty? Won stąd!”. Nie musieli mówić nic więcej, szybko stamtąd zniknąłem ${ }^{88}$.

Kolejnym punktem wytwarzania broni były Zakłady Kolejowe Inchicore. IRA zrekrutowała mężczyzn, już pracujących na miejscu. Dostępne były tam narzędzia potrzebne do produkcji, łatwo było też dokonywać spedycji gotowego produktu ${ }^{89}$. Grupa w Zakładach Inchicore produkowała 50 granatów tygodniowo. Manufaktura na Parnell Street nawet do 100. Nie były one duże, jak opisuje McHugh:

Skorupa była nie większa niż duże kacze jajko. Z przyczepionym zapalnikiem mieścił się w dłoni. Można go było trzymać spokojnie w ręce, w kieszeni spodni i sprawdzał się doskonale ${ }^{90}$.

Produkowano również granaty i substancje zapalające oraz granaty odłamkowe ${ }^{91}$.

Należy jednak pamiętać, że członkowie IRA operowali substancjami wysoce niestabilnymi, a żołnierze na prowincji, mimo pouczających artykułów Ant-Óglách (organie prasowym Irlandzkiej Armii Republikańskiej) na temat środków bezpieczeństwa, nie mieli dużego doświadczenia z pracą $\mathrm{z}$ tego typu substancjami. Skutkowało to po pierwsze problemami psychicznymi, wynikającymi ze świadomości stałego zagrożenia wybuchem ${ }^{92}$. Po drugie zdarzały się wypadki, nierzadko śmiertelne w skutkach, jak chociażby ten opisywany przez Josepha McCarthy'ego z hrabstwa Wexford z dnia 12 października 1920 r. w fabryce IRA w Saltmils.

Tom Gleeson i Michael Conway docinali kable detonatorów. Michael Conway używał szczypiec. Gleeson uderzył w detonator scyzorykiem, którym przecinał kable, wywołując iskrę. W ciągu kilku sekund pomieszczenie wypełniło się błękitnym ogniem. John Timmons i Edward Kelly krzyknęli uciekajcie chłopaki, uciekajcie! Niech Bóg się nad nami zmiłuje! I kiedy wypowiedzieli te słowa, krótka, szybka i głośna eksplozja wysadziła stary dom w powietrze. Była tak potężna, że dach został zmieciony aż na drugą stronę czteroakrowego pola. Trzech mężczyzn: Martin Roche, Robert Walsh

\footnotetext{
88 BMH.WS0531, s. 13-14.

89 BMH.WS0476, s. 12.

90 BMH.WS0664, s. 7.

91 BMH.WS1713, s. 9-10.

92 BMH.WS0664, s. 7.
} 
i Michael Fitzgerald zginęło na miejscu. James Gleeson przeżył jeszcze pół godziny. James Byrne zmarł następnego dnia u Kelly'ego, w Saltmills. Z pozostałych niektórych znaleziono niedługo później poważnie rannych, nagich i krwawiących, czołgających się po ziemi. Inni byli ogłuszeni, błąkali się po okolicy w stanie szoku ${ }^{93}$.

Eksplozja zwróciła uwagę miejscowych władz. Pracownicy, którym udało się przeżyć wybuch, zostali albo aresztowani albo musieli uciekać przed policją.

\section{Transport}

Z oczywistych względów największy dostęp do pojazdów mechanicznych podczas wojny miały siły brytyjskie. Używano trzech rodzajów pojazdów: czołgów, pojazdów opancerzonych i tzw. ciężarówek taktycznych, przy czym tych pierwszych używano bardzo rzadko, głównie by zaprezentować siłę militarną i wzbudzić postrach w siłach irlandzkich. Podczas Wielkiej Wojny Brytyjczycy opracowali projekt samochodu pancernego Rolls-Royce, którego używano również podczas walk z Irlandczykami. Ciężarówki taktyczne dzieliły się natomiast na dwa typy: opancerzone i chronione. Pierwszy rodzaj charakteryzował się blachami grubości cala, drugi natomiast chroniony był przez pół cala blachy. Cal stali mógł chronić brytyjskich żołnierzy nawet przed ostrzałem z karabinu Lee Enfield kaliber $303^{94}$. Zastosowanie tych pojazdów w walkach zmuszało Irlandczyków do ciągłego rozwoju swojej taktyki wojennej. Trzeba było opracować sposób na zaatakowanie chronionych przez pancerz Brytyjczyków i zatrzymanie pojazdu. W tym celu IRA stosowało blokady dróg, np. poprzez zawalanie drzew czy tworzenie rowów ${ }^{95}$. Do ataków na pojazdy opancerzone stosowano również środki wybuchowe i miny ${ }^{96}$. Do perfekcji rozwinięto taktykę zasadzek, w której głównym celem było zatrzymanie pojazdu i zaatakowanie sił nieprzyjaciela. Początkowo odpowiedzią Brytyjczyków na tę taktykę była metoda przejazdu przez trasę z taką prędkością, by uniemożliwić zatrzymanie pojazdu ${ }^{97}$. Nie sprawdzała się ona jednak, a nawet była niebezpieczna, w przypadkach trwałego zablokowania drogi. W związku z tym opracowano nową metodę: ciężarówki podróżowały w konwojach, ochraniane przez znacznie większą liczbę żołnierzy niż w początkowych etapach konfliktu. Dodatkowo pojazdy

93 BMH.WS1507, s. 3.

${ }^{94}$ W.H. Kautt, Ambushes and armour in the War of Independence: Kilmichael reconsidered, „History Ireland” 2010, t. 18, nr 2, s. 38.

95 C. Townshend, op. cit., s. 558.

${ }^{6}$ BMH.WS0689, s. 5.

${ }^{97}$ C. Townshend, op. cit., s. 492. 
uzbrajane były w karabiny maszynowe, co uniemożliwiało mniejszym grupom IRA efektywną walkę z siłami brytyjskimi. Nie zawsze jednak siły brytyjskie przestrzegały zasad poruszania się w konwojach, a każdy ich błąd był wykorzystywany przez IRA ${ }^{98}$.

Strona irlandzka również próbowała pozyskiwać pojazdy, jednak ich możliwości były ograniczone. Próbowano kradzieży ciężarówek brytyjskich, a także „rekwirowania” pojazdów cywilnych. W czasie pokoju posiadanie automobilu byłoby oznaką prestiżu, jednak w trakcie wojny o niepodległość właściciele pojazdów nie mieli dużo czasu, by się nimi nacieszyć. Jeśli nie zostały one zarekwirowane przez IRA, zabezpieczała je policja, by uprzedzić republikanów ${ }^{99}$. Bardziej dostępnym środkiem transportu były natomiast rowery, ale one również stanowiły towar luksusowy. Nie można było ich też używać podczas każdej akcji, bowiem przyciągały wzrok i budziły zainteresowanie szczególnie na terenach wiejskich ${ }^{100}$.

\section{Pomoc medyczna, wyżywienie i umundurowanie}

Dostęp członków IRA do pomocy medycznej był kwestią skomplikowaną. W dobrej sytuacji byli żołnierze działający w dużych miastach i Dublinie. Relatywnie łatwo było tam znaleźć lekarza, chętnego do udzielenia pomocy. Szpitale otrzymały co prawda ścisłe instrukcje, by informować władze o każdym pacjencie zgłaszającym się z ranami postrzałowymi lub spowodowanymi wybuchem, jednak problem ten rozwiązywano poprzez szybkie udzielanie pomocy medycznej, zwalnianie pacjenta i zgłaszanie przypadku władzom dopiero, kiedy opuścił on już placówkę ${ }^{101}$.

Inaczej sytuacja wyglądała na prowincji, gdzie operowały lotne kolumny IRA. Żołnierze ci stale się przemieszczali, co utrudniało przestrzeganie podstawowych zasad higieny. Dodatkowo często byli niedożywieni, a trudne warunki atmosferyczne i wilgoć wpływały na rozwój wielu chorób. Największym problemem lotnych kolumn był świerzb. Żołnierzy nim dotkniętych starano się izolować od reszty oddziału, lub w poważnych przypadkach zwalniać ze służby. Przypadłość leczono za pomocą maści siarkowej. Brak higieny skutkował też wszawicą i różnego rodzaju infekcjami ${ }^{102}$. Starano się temu przeciwdziałać za pomocą instrukcji w Ant-Óglách, jednak nie dawało to rezultatów. Ciężko też było zapewnić chorym żołnierzom stałą pomoc

${ }^{98}$ W.H. Kautt, Studying the Irish Revolution as Military History: Ambushes and Armour, „The Irish Sword (The Journal of Military History Society of Ireland)” 2010, t. 25, nr 108, s. 12.

${ }_{99}$ P. Cottrell, op. cit., s. 72.

100 BMH.WS0535, s. 3.

101 BMH.WS0682, s. 3.

102 C. Townshend, op. cit., s. 440. 
medyczną. Na prowincji działała ograniczona liczba lekarzy, więc siłom brytyjskim łatwo było monitorować, czy nie udzielają oni pomocy republikanom. Dodatkowo żołnierze lotnych kolumn często odmawiali przyjmowania pomocy od kobiet lekarzy lub sanitariuszek Cumann na BBan $^{103}$, co jeszcze bardziej ograniczało pulę ludzi gotowych ich leczyć104. Ograniczony dostęp do pomocy medycznej skutkował rozwojem metod niekonwencjonalnych. Np. specjaliści pracujący w manufakturach broni IRA, wystawieni na działanie toksycznych wyziewów, leczyli objawy zatrucia pijąc duże ilości mleka ${ }^{105}$. Zdarzały się też wypadki, w których poważne urazy nie były w ogóle badane przez lekarzy - tak było np. w przypadku Jamesa O’Donovana, który podczas prac nad ciekłą formą gazu bojowego prysnął sobie nim w twarz.

W trakcie jednego z tych eksperymentów nastąpił wybuch i moją twarz oblał ciekły gaz. Myślałem, że oślepłem, ale na szczęście po piętnastu lub dwudziestu minutach mogłem już otworzyć oczy. Twarz pokrywały pęcherze. Musiałem wziąć wolne na jakiś tydzień. Po eksplozji, kiedy już odzyskałem wzrok [nadzorca] chciał, żebym poszedł z tym do szpitala świętego Wincenta, ale nie mogłem się tam udać - zadawaliby mnóstwo niewygodnych pytań ${ }^{106}$.

Odwiezienie osoby rannej do szpitala, nawet przy współpracy personelu medycznego zawsze wiązało się z ryzykiem. Policja zaczynała wtedy śledzić powiązania osoby hospitalizowanej i w ten sposób mogła zostać zdradzona cała komórka IRA. Szczególnie niebezpieczną sytuację tego typu opisuje w swoich zeznaniach Vincent C. Ellis, lekarz psychiatra, do którego po wydarzeniach Krwawej Niedzieli ${ }^{107}$ zgłosili się republikanie z prośbą o pomoc dla młodego żołnierza. Chłopak zaczął mieć problemy psychiczne w związku z egzekucjami, w których brał udział. Dowództwo IRA chciało odizolować chłopaka, którego dręczyły wyrzuty sumienia by nie dopuścić do tego, by zgłosił się na policję. Ellis zgodził się. Młody człowiek został odizolowany. Przydzielono mu też pielęgniarzy sympatyzujących z ruchem republikańskim, którzy mieli go pilnować ${ }^{108}$.

Kwestia zdrowia psychicznego w wojnie o niepodległość jest szczególnie ciekawa. Oprócz rzeczywistych objawów chorób psychicznych, wywołanych chociażby ciągłym zagrożeniem, pojawiały się również przypadki

${ }^{103}$ Cumann na mBan - irlandzka, republikańska organizacja paramilitarna kobiet, założona w 1914 r. Formacja pomocnicza IRA.

104 Ibidem, s. 682.

105 BMH.WS0664, s. 6.

106 BMH.WS1713, s. 5.

107 Termin odnoszący się do wydarzeń z 21 listopada 1920 r. Tego dnia siły IRA dokonały skoordynowanej akcji likwidacji agentów brytyjskiego wywiadu.

${ }^{108}$ BMH.WS0682, s. 1-2. 
symulowania szaleństwa przez republikanów, by uniknąć konsekwencji swoich czynów. Ellis opisuje w swoich zeznaniach przypadek swojego współpracownika, jednego z pielęgniarzy szpitala.

Kiedy zaczął się nalot, jeden z pielęgniarzy na zmianie był zagrożony aresztowaniem. Zamknął się w jednej z cel z miękkimi ścianami i zaczął zachowywać się jak zupełny czubek. Kiedy nalot się zakończył, powrócił do obowiązków pielęgniarza $^{109}$.

Podobną taktykę przyjął jeden z trzech żołnierzy IRA, których podczas zawieszenia broni Ellis miał odeskortować do kraju. 0 ile dwóch pozostałych przejawiało objawy chorób psychicznych (w dzisiejszych czasach prawdopodobnie powiązano by je z zespołem stresu pourazowego), o tyle trzeci z panów, o nazwisku Leahy zwyczajnie udawał szaleńca.

Człowiek ten był zdrowy psychicznie, ale kiedy został aresztowany miał przy sobie broń. Było to przestępstwo karane śmiercią, więc doradzono mu udawanie szaleńca. Brytyjski oficer medyczny i miejscowy lekarz ze szpitala psychiatrycznego uznali go za chorego psychicznie, więc uniknął egzekucji. Wszystko było z nim w porządku. Był całkowicie zdrowy - w każdym tego słowa znaczeniu - i powrócił do swoich przyjaciół, kiedy tylko dotarliśmy do Dublina ${ }^{110}$.

Trudno jest kompleksowo omówić kwestię wyposażenia i umundurowania strony irlandzkiej. Republikanie podczas powstania wielkanocnego stworzyli w miarę ujednolicony mundur, ale po powstaniu już go nie stosowano. Wzór munduru Wolnego Państwa natomiast został opracowany już po wojnie. W trakcie konfliktu irlandzko-brytyjskiego z racji natury wojny partyzanckiej nie stosowano jednolitego umundurowania, a wyposażenie żołnierzy było kwestią całkowicie prywatną. Ant-Óglách udzielał wskazówek odnośnie do doboru materiałów w swoich wytycznych dla żołnierzy Lotnych Kolumn ${ }^{111}$. Sugerowano raczej ubrania z wełny niż z lnu czy bawełny. Akcentowano potrzebę posiadania więcej niż jednej pary ciepłych wełnianych skarpet. Każdy z żołnierzy powinien też posiadać utensylia potrzebne do naprawy ubrań (nici, igły). Zmianę bielizny zalecano przynajmniej raz w tygodniu. Podstawowym elementem wyposażenia żołnierza były jednak wygodne, najlepiej odrobinę za duże, buty, które nie powodowałyby dyskomfortu podczas przemarszu. Duża część wskazówek co do sprzętu dotyczyła

109 Ibidem, s. 2.

110 Ibidem s. 2-3.

111 Lotne Kolumny - grupowały żołnierzy IRA poszukiwanych przez siły brytyjskie. Formacje te ciągle się przemieszczały. Celem kolumn było atakowanie oddziałów brytyjskich, stosując taktykę zasadzek i inne metody charakterystyczne dla wojny partyzanckiej. 
ich poprawnego pastowania i zabezpieczania przed wilgocią - przestrzegano np. przed używaniem do tego celu oleju silnikowego ${ }^{112}$.

Były prowadzone prace nad stworzeniem odzieży ochronnej - próby O’Donovana z gazem bojowym miały na celu właśnie testowanie możliwości masek gazowych i gogli ochronnych, a nie użycie gazu w konflikcie. Sam O’Donovan żartował później, że był jedyną ofiarą gazu bojowego podczas wojny ${ }^{113}$. Maski nie weszły jednak do powszechnego użycia. Nie było zresztą takiej potrzeby, ponieważ Brytyjczycy nie użyli przeciw IRA gazów bojowych. Strona brytyjska również nie używała na szeroką skalę odzieży ochronnej. W źródłach znaleźć można informacje o noszeniu pancerzy ochronnych przez policjantów w pierwszym etapie konfliktu, jednak później siły brytyjskie używały ich rzadko. Od $1921 \mathrm{r}$. funkcjonowała forma pancerza bardziej zbliżona do współczesnej kamizelki kuloodpornej, jednak nie cieszyła się ona popularnością, ponieważ nie zapewniała ona ochrony przed odłamkami granató $w^{114}$.

Nawet wyżywienie Lotne Kolumny zapewniały sobie same lub korzystały z pomocy miejscowej ludności. Dowództwo zalecało jedynie ciągłą kontrolę nad źródłami zaopatrzenia. Akcentowano potrzebę zapewnienia żołnierzom stałych porcji warzyw i mięsa, jednak podstawą diety były ziemniaki ${ }^{115}$.

\section{Kryjówki oraz sposoby łączności}

Do skutecznego prowadzenia wojny partyzanckiej potrzebna jest rozbudowana sieć kryjówek i magazynów. W przeważającej większości były to posesje należące do osób sympatyzujących z ruchem republikańskim przekazywane do użytku armii. Przykładem można mnożyć. Jedna z dublińskich manufaktur broni mieściła się w sklepie żelaznym Pani Baker naprzeciwko Centrali Telefonicznej, będącej pod ciągłą strażą brytyjskich jednostek.

Pani Baker zasługuje na wielkie uznanie za ryzyko, które podjęła. Nie była młodą kobietą, ale był w niej patriotyczny duch. Irlandzcy żołnierze potrzebowali pomocy, a ona jej udzieliła nie zważając na ryzyko, czy koszta i zawsze pozostawała w dobrym humorze. Nieliczne kobiety z wojskowymi strażnikami przed domem podjęłyby takie ryzyko ${ }^{116}$.

Kolejnym przykładem osoby nienależącej do IRA, ale udzielającej schronienia jej członkom może być Oliver S. John Gogarty. Czarno-Brunatni zagrozili życiu jego córeczki, kiedy ta bawiła się w parku. Gogarty postanowił

112 Equipment, „An t-Óglách” 1918, vol. 1, no. 5, s. 2, http://antoglach.militaryarchives.ie/ PDF/1918_10_29_Vol_1_No_5_An_t-Oglac.pdf, dostęp: 12.09.2018.

113 BMH.WS1713, s. 3-4.

114 W.H. Kautt, Studying the Irish Revolution..., s. 263-264.

115 Equipment, „An t-Óglách” 1918, vol. 1, no. 2, s. 3.

116 BMH.WS0664, s. 29. 
skontaktować się ze swoim pacjentem, o którym wiedział, że jest bliskim współpracownikiem Michaela Collinsa, by udzielić pomocy republikanom. Jak sam opisuje w swoich zeznaniach:

Dałem mu zapasowe klucze do mojego domu pod numerem 15 Ely Place i przygotowałem zaułek za domem tak, by Collins, gdyby zaszła potrzeba, mógł użyć mojego ogrodu by przedostać się do S. Stephen'sGreen. [...] Aby ułatwić wspinaczkę na mur, ułożyłem pod nim, nieopodal dużego jesionu, kilka kanistrów z benzyną. Następnie przekazałem informacje o tych przygotowaniach do Batta O'Connora, który miał poinformować o nich Collinsa. O'Connor przekazał mi później jego podziękowania ${ }^{117}$.

Poszczególne komórki irlandzkiego państwa podziemnego również funkcjonowały w prywatnych mieszkaniach sympatyków, często zmienianych, by uniknąć podejrzeń. Podobnie było z biurem Collinsa, które zmieniało lokalizację. W krótkim okresie czasu funkcjonowało ono w wielu różnych miejscach, Cathleen Napoli-McKenna, maszynistka w biurze propagandy Dáil Éireann, wymieniła w swoich zeznaniach 4 różne adresy ${ }^{118}$.

Najbardziej znaną kryjówką członków IRA był Hotel Korona. Noce spędzała tam duża liczba Ochotników i osób powiązanych z ruchem republikańskim. Co ciekawe, władze wiedziały o tym procederze, jednak przed Krwawą Niedzielą tylko raz przeprowadziły nalot na hotel, który zakończył się niepowodzeniem, gdyż Czarno-Brunatni nie rozpoznali poszukiwanych osób ${ }^{119}$.

Kwestia kryjówek na prowincji była bardziej skomplikowana. Dowódcy musieli znaleźć budynki, które były w stanie pomieścić wiele osób. Szczególnie dobre do tego celu były pustostany, ponieważ cywilom udzielającym schronienia żołnierzom IRA groziły bolesne reperkusje. Kryjówka taka musiała być co najmniej w części osłonięta, by móc odeprzeć atak nieprzyjaciela, potrzebowała też dostępu do wody. W An t-Óglách znalazło się wiele wskazówek na temat utrzymania kryjówek w czystości, tak by ograniczyć rozprzestrzenianie się chorób i szkodników ${ }^{120}$.

Opracowanie dobrze funkcjonującego sposobu przekazywania informacji było niezwykle ważne dla działań wojennych. IRA opierała swój system łączności głównie na kurierach. Do tego zadania rekrutowano głównie ludzi, których praca lub styl życia wymagały ciągłego przemieszczania się, co dawało przykrywkę dla ich podziemnej działalności ${ }^{121}$. Dużą część pracy wykony-

\footnotetext{
117 BMH.WS0700, s. 1.

118 BMH.WS0643, s. 7.

119 BMH.WS0749, s. 1-2.

120 Eqipment, „An t-Óglách” 1918, vol. 1, no. 5, s. 2.

121 BMH.WS1078, s. 7.
} 
wały kobiety. W początkowych etapach wojny miały one więcej swobody poruszania się niż mężczyźni i nie budziły podejrzeń policji. Z biegiem czasu jednak siły brytyjskie zorientowały się, że kobiety mogą pełnić role kurierów. Powszechnie stosowano też tajne znaki, np. gaelickie słowa zapisane na kartkach, dla potwierdzenia afiliacji kuriera ${ }^{122}$. Grupy saperów IRA zapewniały również telefoniczne środki łączności polowej (telefony polowe były w użyciu już od 1870 r.) ${ }^{123}$. Saperzy mieli również za zadanie sabotowanie łączności wroga - szczególnie podczas dużych akcji takich jak np. spalenie Izby Celnej. W An t-Óglách zachęcano do komunikacji za pomocą alfabetu morsa i posługiwania się sygnalizacją świetlną ${ }^{124}$.

\section{Zakończenie}

Natura konfliktu wymuszała na Irlandczykach ciągłą improwizację oraz potrzebę dostosowania się do zmiennych czynników. Republikanie zdołali nie tylko pozyskać fundusze na prowadzenie działań wojennych, ale również zorganizować za te pieniądze stałe dostawy broni oraz manufaktury produkujące środki wybuchowe. Sprawiło to, że imperium brytyjskie, mimo wyraźnej przewagi miało olbrzymie trudności ze stłumieniem niepokojów społecznych na Wyspie. Trudniejszy dostęp do opieki medycznej, środków transportu czy aprowizacji nie stanął na przeszkodzie Irlandzkiej Armii Republikańskiej. Strona irlandzka szybko dostosowywała się do zmieniających się okoliczności i w pomysłowy sposób rozwiązywała pojawiające się problemy.

Strona brytyjska natomiast nie wykorzystała w konflikcie swojej oczywistej przewagi wynikającej z wcześniej istniejącego i sprawnego zaplecza. Ciągłe polepszające się przygotowanie Irlandczyków do konfliktu oraz metody ich działań wymuszały na Brytyjczykach elastyczne dostosowywanie się do zmieniających się warunków.

122 BMH.WS0565, s. 1.

123 BMH.WS0689, s. 4-5.

124 Notes on training, „An tóglách” 1918, vol. 1, no. 3, s. 3. 


\section{BIBLIOGRAFIA}

\section{Źródła}

Dokumenty Biura Historii Militarnej Irlandii, http://www.bureauofmilitaryhistory.ie/reels/ bmh/, dostęp: 12.09.2018.

Zeznania numer: BMH.WS0828, BMH.WS0519, BMH.WS0684, BMH.WS0777, BMH. WS0776, BMH.WS0531, BMH.WS0847, BMH.WS1360, BMH.WS0554, BMH.WS0597, BMH.WS0814, BMH.WS1713, BMH.WS1507, BMH.WS0664, BMH.WS0476, ВMH. WS0689, BMH.WS0535, BMH.WS0682, BMH.WS0664, BMH.WS0682, BMH.WS0700, BMH.WS0643, BMH.WS0689, BMH.WS0565, BMH.WS1078, BMH.WS0749.

Stenogram debat Dáil Éireannz dnia 2 kwietnia 1919 r. Propozycje finansowe, http://oireachtas debates.oireachtas.ie/debates\%20authoring/debateswebpack.nsf/takes/dail 1919040200022 ?opendocument, dostęp: 12.09.2018.

\section{Prasa}

Equipment, „An t-Óglách” 1918, vol. 1, no. 2, http://antoglach.militaryarchives.ie/PDF/ 1918_09_14_Vol_1_No_2_An_t-Oglac.pdf, dostęp: 12.09.2018.

Equipment, „An t-Óglách” 1918, vol. 1, no. 5, http://antoglach.militaryarchives.ie/PDF/ 1918_10_29_Vol_1_No_5_An_t-Oglac.pdf, dostęp: 12.09.2018.

Notes on training, „An t-Óglách” 1918, vol. 1, no. 3, http://antoglach.militaryarchives.ie/PDF/ 1918_09_30_Vol_1_No_3_An_t-Oglac.pdf, dostęp: 12.09.2018.

\section{Opracowania}

Carroll M.F., Money for Ireland: Finance, Diplomacy, Politics, and the First Dáil Éireann Loans, 1919-1936, Westport 2002.

Cottrell P., The Anglo-Irish War. The Troubles of 1913-1922, Oxford 2006.

Evans G., The raising of the first internal Dái lÉireann Loan and the British responses to it, 1919-1921 (Praca magisterska obroniona w 2012 r. na Uniwersytecie w Maynooth), http://eprints.maynoothuniversity.ie/4012/1/MLitt___Gary_Evans.pdf, dostęp: 12.09.2018.

Graubard S.R., Military Demobilization in Great Britain Following the First World War, „The Journal of Modern History" 1947, t. 19, nr 4, s. 297-311.

Kautt W.H., Ambushes and Armour in the War of Independence: Kilmichael reconsidered, „History Ireland” 2010, t. 18, nr 2, s. 36-38.

Kautt W.H., Ambushes and Armour: The Irish Rebellion 1919-1921, Newbridge 2010.

Kautt W.H., Studying the Irish Revolution as Military History: Ambushes and Armour, „The Irish Sword (The Journal of Military History Society of Ireland)" 2010, t. 25, nr 108, s. 253-257.

Korzun M., 1000 słów o materiałach wybuchowych i wybuchu, Warszawa 1986.

McDowell R.B., Crisis and Decline: The Fate of the Southern Unionists, Dublin 1997.

Mitchell A., Revolutionary Government in Ireland: Dáil Éireann, 1919-22, Dublin 1995.

Pattison G., The British Army's Effectiveness in the Irish Campaign 1919-1921 and the Lessons for Modern Counterinsurgency Operations, with Special Reference to C3I Aspects, materiały 
Cornwallis XIV: Analysis of Societal Conflict and Counter-Insurgency, http://www.ismor. com/cornwallis/cornwallis_2009/6-Pattison-CXIV.pdf, dostęp: 12.09.2018.

Regan J.M., Myth and the Irish State, Newbridge 2013.

Townshend C., The Republic: The Fight For Irish Independence, London 2013.

Zins H., Historia Anglii, Warszawa 1995.

Antonina Pawłowska

\section{WEAPONRY AND EQUIPMENT OF THE IRISH REPUBLICAN ARMY DURING THE IRISH WAR OF INDEPENDENCE (1919-1921)}

\footnotetext{
The article presents an analysis of the logistics and the supply base of the Irish side 1 of the conflict during the Tan War. The issues examined are: the state of the finances of both sides of the conflict and the methods of raising funds needed to wage war; the matter of firearms and acquiring them; production and use of the explosives. Means of transport used by both sides are also considered. as well as medical assistance, uniforms and provisioning. The article is based on witnesses' testimonies gathered. by the Bureau of the Military History.
}

Keywords: logistics, equipment, weaponry, Irish Republican Army, transport, explosives, firearms, finances. 